\title{
Positive and negative emotional responses to work- related trauma of intensive care nurses in private health care facilities
}

\author{
Authors: \\ Diane Elkonin ${ }^{1}$ \\ Lizelle van der Vyver ${ }^{2}$ \\ Affiliations: \\ ${ }^{1}$ Department of Psychology, \\ Nelson Mandela \\ Metropolitan University, \\ South Africa \\ ${ }^{2}$ Aurora Rehabilitation \\ Hospital, Mangold Park, \\ Port Elizabeth, South Africa \\ Correspondence to: \\ Diane Elkonin \\ Email: \\ diane.elkonin@nmmu.ac.za \\ Postal address: \\ PO Box 77000, Port \\ Elizabeth 6000, South Africa \\ Dates: \\ Received: 06 May 2009 \\ Accepted: 10 Oct. 2010 \\ Published: 21 Apr. 2011 \\ How to cite this article: \\ Elkonin, D.\& Van der \\ Vyver, L., 2011, 'Positive \\ and negative emotional \\ responses to work-related \\ trauma of intensive care \\ nurses in private health \\ care facilities', Health SA \\ Gesondheid 16(1), Art. \\ \#436, 8 pages. doi:10.4102/ \\ hsag.v16i1.436
}

(C) 2011. The Authors. Licensee: OpenJournals Publishing. This work is licensed under the Creative Commons Attribution License.
Intensive care nursing is a stressful occupation and nurses are continually subjected to both primary and secondary trauma. Responses may be positive in the form of compassion satisfaction, or negative in the form of compassion fatigue. However, nurses tend to deny the negative impact of secondary trauma which leads to the silencing response and subsequent burnout. This article explores and describes the presence of these emotions and the relationships between them. A quantitative approach with a non-probability sampling method was used. The sample consisted of 30 registered nurses working in private health care intensive care units in East London, Eastern Cape. Data were gathered via the Professional Quality of Life Scale: Compassion Satisfaction and Fatigue Subscales - Revision IV (ProQOL - R-IV) and the Silencing Response Scale and were analysed according to descriptive statistics and correlation coefficients. Findings suggest a high risk for compassion fatigue, a moderate risk for burnout and the silencing response and moderate potential for compassion satisfaction. A marked negative relationship was found between compassion satisfaction and burnout and a substantial positive relationship between compassion fatigue and burnout, as well as compassion fatigue and the silencing response.

Intensiewesorgverpleging is ' $\mathrm{n}$ stresvolle beroep en verpleegsters word gedurig aan beide primêre en sekondêre trauma blootgestel. Reaksie hierop kan óf positief wees, in die vorm van empatie-tevredenheid, óf negatief, in die vorm van empatie-uitputting. Verpleegsters is egter geneig om die negatiewe impak van sekondêre trauma te ontken, wat gevolglik tot stilswye en uitbranding kan lei. Hierdie artikel ondersoek en beskryf die teenwoordigheid en verwantskap tussen hierdie emosies. ' $n$ Kwantitatiewe benadering met ' $n$ nie-waarskynlikheidsteekproefmetode is gebruik. Die steekproef het bestaan uit 30 geregistreerde verpleegsters wat in privaat-intensiewesorgeenhede in Oos-Londen in die Oos-Kaap werk. Data is met behulp van die vierde hersiening van die 'Professional Quality of Life Scale: Compassion Satisfaction and Fatigue Subscales' en die 'Silencing Response Scale' ingevorder en verwerk met verwysing na beskrywende statistieke en korrelasiekoëffisiente. Die resultate dui op 'n hoë risiko vir empatie-uitputting, ' $n$ matige risiko vir uitbranding en die stilswye-reaksie, sowel as 'n matige potensiaal vir empatie-tevredenheid. 'n Beduidende negatiewe verwantskap blyk tussen empatie-tevredenheid en uitbranding te bestaan, terwyl 'n aansienlik positiewe verwantskap tussen empatie-uitputting en uitbranding en empatieuitputting en die stilswye-reaksie bestaan.

\section{Introduction}

Health care professionals, particularly in trauma care, are subjected to significant stress. The combination of trauma, compassion fatigue and burnout are occupational hazards and have a negative impact on the quality of life and the psychological health of the nurse, as well as negative implications for patient care (Mathiva 2002:22-23; Rothmann, Rothmann \& Van der Colff 2006:22-33; Sherman 2004:48-56).

\section{Intensive care nursing}

Intensive care nursing is particularly stressful owing to the nature and extent of care required by patients in intensive care units (Lally \& Pearce 1996:17-25). Intensive care nurses who are surrounded by 'the extreme intensity of trauma-inducing factors' (Figley 1995:15) and constant exposure to serious illness and human tragedy (Vettor, Kosinski \& Frederick 2000:216-219) are exposed to high emotional risk and may deliver compromised care (Romano 1992:190-202). The impact on nurses include high staff turnover (Cartledge 2001:348-355) and unrealistic self 
expectations (Sherman 2004:48-56), whilst exposure to death and bereavement can increase the nurses' awareness of their own losses and vulnerabilities (Sherman 2004:48-56). The loss of a patient may be equated with personal failure and loss of self-esteem (Jisika 1995:444-466) and is regarded, psychologically, as the most distressing experience for a nurse (Tyler \& Ellison 1994:469-476). These stressors contribute to the development of secondary and vicarious trauma and, if untreated, burnout.

\section{Secondary trauma}

Secondary trauma is an understudied and controversial phenomenon (Zimering, Munroe \& Gulliver 2003). The terms 'vicarious trauma' (McCann \& Pearlman 1990: 131-149), 'secondary traumatic stress' (Stamm 1997:1-8) and 'compassion fatigue' (Joinson 1992:116-122) have become cornerstones in the vernacular of describing the effects on caregivers who work with trauma survivors (Gentry 2002:37-61). Research regarding secondary trauma (Friedman \& Ortlepp 2002:213-222), particularly as experienced by South African caregivers, is relatively recent. Regardless of these interchangeable labels, the consequences of working with trauma victims over time appear to be the same (Collins \& Long 2003:417-424).

\section{Vicarious trauma}

Vicarious trauma is 'the cumulative transformation in the inner experience of the therapist that comes about as a result of empathic engagement with the client's traumatic material' (Pearlman \& Saakvitne 1995:31). Empathising with a person who has been traumatised may come with a personal and professional cost for the caregiver. Although empathy enhances a caregiver's caring ability, it also increases the caregiver's vulnerability to the negative effects of caring. This experience can affect the caregiver's belief system, cognitive schemas, identity and spirituality (Collins \& Long 2003:417-424; Romey 2005:1-47). Secondary traumatic stress may develop as a natural consequence of caring for traumatised persons and is not necessarily problematic (Collins \& Long 2003:417-424). Although secondary trauma cannot be avoided or eliminated, its effects can be modified or reduced if adequately addressed. Positive consequences associated with this nature of work include personal growth, spiritual connection, hope and respect for human resilience (Friedman \& Ortlepp 2002:231-222).

\section{Compassion satisfaction}

Compassion plays a pivotal role in the equation of human services, specifically in the nursing profession (Hem \& Heggen 2004:19-31). According to Stamm (2002:113) 'compassion satisfaction may be happiness with what one can do to make the world in which one lives a reflection of what one thinks it should be.' Positive outcomes of stress may be heightened motivation and a sense of satisfaction in overcoming obstacles or challenges (Park, Cohen \& Murch 1996:71-105), which relates positively to compassion satisfaction. Paradoxically, a high level of compassion satisfaction may therefore coexist with a high level of compassion fatigue in caregivers when their professional activities carry significant and positive meanings for them. Positive affect may co-occur with distress during a given period of time (Folkman \& Moskowitz 2000:647-654). Compassion satisfaction is a protective factor that buffers the potentially negative consequences of exposure to traumatic events (Collins \& Long 2003:417-424) and subsequent possible burnout.

\section{Compassion Fatigue}

Joinson (1992:116-122) coined the term 'compassion fatigue' when he noted that health care professionals lose their compassion as a result of repeated exposure to suffering during their work. Figley (1995:1-21) defines compassion fatigue as the specific secondary traumatic stress disorder (STSD) resulting from deep involvement with a primarily traumatised person. However, compassion fatigue was chosen as a reference term due to its more accessible framing and connotation than STSD, which has a more pathological connotation. The fact that the term compassion fatigue incorporates the exhaustion associated with the provision of support also led to its preferential use. Compassion fatigue is not merely a response to trauma exposure; it entails trauma exposure whilst in a helping capacity. Prolonged exposure to stress, secondary trauma and vicarious trauma may lead to burnout, which challenges the caregiver's ability to provide an effective service while maintaining personal and professional relationships (Collins \& Long 2003:417-424).

\section{Burnout}

Burnout is defined as physical, emotional and mental exhaustion, which manifests as 'physical depletion, feelings of helplessness, hopelessness, emotional drain and the development of a negative self-concept and negative attitudes toward work, life and other people' (Aronson, Kafrey \& Pines 1981:15). It equates to an extreme form of compassion fatigue and is particularly prevalent amongst nurses (Edwards et al. 2000:7-14; Garrett \& McDaniel 2001:91-96; Kilfedder, Power \& Wells 2001:383-396). Burnout may be exacerbated by work overload (Duquette et al. 1994:337-358; Govender 2007), role uncertainty (Chaboyer, Dunn \& Najman, 2001:153-161), characteristics of the client population (Prosser et al. 1997:51-59), low remuneration and low work status (McCloed 1997:569-574), conflicts between work and home demands (Nolan, Cushway \& Tyler 1995:3639) and individual coping strategies (Thornton 1992:261-271).

\section{The silencing response}

The cumulative effects of compassion fatigue and burnout, if not addressed by the caregiver, can lead to the activation of the silencing response or active avoidance (Sheldon 2000:12), which is viewed as a subcomponent of compassion fatigue. This response can be either an indication of the experience of compassion fatigue or an attempt of a caregiver to avoid the negative affect associated with compassion fatigue. The silencing response (Danielli 1984:23-42) refers to the inability of caregivers to pay attention to the stories or experiences of their patients and the tendency to direct the conversation 
rather to less distressing material. The silencing response occurs when patients' experiences are overwhelming, beyond the caregiver's scope of comprehension and desire to know, or simply spirals past the helper's sense of competency. It may be triggered as a defence mechanism following the revelation of a particularly traumatic patient memory. Compassion-fatigued caregivers use the silencing response to end their own discomfort and pain. Fear of judgement, reprisal or ridicule, fear of exposing oneself emotionally, illusions of omnipotence, and difficulty trusting other professionals seem to contribute to the silencing response and tend to prevent caregivers from reaching out when they require help.

Work-related stress with the concomitant emotions provoked specifically in intensive care nurses is well documented (Bailey, Steffen \& Grout 1980:15-25; Cartledge 2001:348-355; Lally \& Pearce 1996:17-25). Excessive stress can negatively impact the ability of the nurse to render appropriate care to the patients, but early identification of the negative consequences such as compassion fatigue and burnout, and intervention to ameliorate these effects would be beneficial to both professional nurses and the patients in their care.

\section{Objectives of the study}

The aim of this study was to explore and describe the work-related positive and negative emotions (compassion satisfaction, compassion fatigue, burnout and the silencing response) experienced by intensive care nurses working in private health care facilities in East London. The study further aimed to investigate the relationship between compassion satisfaction, compassion fatigue, burnout and the silencing response in this sample.

\section{Research method and design}

A quantitative exploratory-descriptive design was used during the study and the method of data collection was via self-report and investigator-administered survey-type questionnaires.

\section{Sampling}

Three intensive care units (ICUs) were included in the study with a total staff component of 75 nurses. A non-probability convenience sampling technique was used to select 30 professional nurses, registered with the South African Nursing Council, with a minimum of 6 months' intensive care nursing experience. This sample size was considered sufficient to perform the basic statistical procedures of the research (De Vos et al. 2005:192-195) and represents 40\% of the total population. No exclusion was made on the basis of gender, culture or socio-economic status. However, as questionnaires were available only in English, participants were required to have a comprehensive grasp of English.

\section{Measures}

A biographical questionnaire, as well as the Professional Quality of Life Scale: Compassion Satisfaction and Fatigue
Subscales - Revision IV (ProQOL - R-IV) and the Silencing Response Scale were used.

The biographical questionnaire requested the following information, (1) age, (2) gender, (3) language, (4) qualifications, (5) years of nursing experience and (6) years of intensive care nursing experience. The consequences of exposure to secondary trauma and post-traumatic stress disorder (PTSD) symptomology were assessed by the ProQOL - R-IV, which is a cross-cultural instrument and measures respondents' potential for experiencing both the positive and the negative consequences of providing care to traumatised persons. It consists of 30 statements divided into three discrete subscales, (1) Compassion satisfaction, (2) Burnout and (3) Compassion fatigue, with 10 statements corresponding to each of the subscales. It is scored according to a 6-point Likert scale that ranges from 'never' to 'very often'. Reverse scoring is used for some of the statements pertaining to burnout. Attendant scores for these responses range from zero to five. Cut scores based on the 75th percentile indicate relative risks or protective factors (Stamm 2005:13). The average score on the Compassion Satisfaction subscale is 37 (s.d. = 7; alpha scale reliability $=0.87$ ). Scores below 32 indicate low potential for compassion satisfaction, scores between 32 and 41 represent moderate potential, and scores above 41 indicate high potential. The average score on the Compassion Fatigue subscale is 13 (s.d. $=6$; alpha scale reliability $=0.80$ ). Scores lower than 8 are indicative of low risk for compassion fatigue, scores between 8 and 17 indicate moderate risk and scores above 17 represent high risk for compassion fatigue. The average score on the Burnout subscale is 22 (s.d. = 6; alpha scale reliability $=0.72$ ). A score below 17 indicates low risk for burnout, one between 17 and 28 a moderate risk and scores above 28 indicate a high risk for burnout (Stamm 2005:5).

Burnout usually has a gradual onset, whilst compassion fatigue typically has a sudden onset and is associated with a particular event. Compassion satisfaction and burnout rarely occur simultaneously, whereas the simultaneous presence of compassion fatigue and burnout appears to suggest the most negative outcome. Compassion satisfaction is regarded as a moderator of compassion fatigue (Stamm 2005:12). It is not atypical for caregivers who retain an altruistic desire to help whilst working in distressing situations to be at high risk for experiencing compassion fatigue whilst simultaneously experiencing high compassion satisfaction. The ProQOL-R-IV has been used in studies in more than 30 countries, including South Africa (Caldas da Costa 2001; Nkosi 2002). It is available, amongst others, in English, French, Spanish, Hebrew and German.

The Silencing Response Scale exhibits internal reliability with an alpha co-efficient of 0.69 and a split-half reliability of 0.63 (Baranowsky 2002:155-170). The scale comprises 15 statements and is scored in a Likert-type manner from 'rarely/never' to 'always'. Scores between 0 and 20 indicate minimal risk for activation of the silencing response, whilst those between 21 
and 40 indicate some risk. Scores between 41 and 94 indicate moderate risk and those from 95 to 150 represent high risk. The Silencing Response Scale has a significant positive correlation with the ProQOL - R-IV Compassion Fatigue Scale revised at the $p=0.02$ level (Baranowsky 2002:155-170). As compassion fatigue scores increase, silencing response scores also increase, suggesting that compassion fatigue may be an umbrella under which the silencing response rests.

\section{Procedure}

Approval for the study was obtained from the National Training and Development Manager of Life Group, who manages two health care facilities in East London. Participants were informed of the nature, purpose and procedure of the study and were advised of their right to anonymity. Each participant was provided with an envelope containing an information letter, a voluntary consent form and the three questionnaires. Due to shift work conditions and the unpredictable workload in ICUs, process managers administered the questionnaires to the participants at a convenient time. The researcher briefed the managers regarding administration of the questionnaires. Anonymity was guaranteed and personal details were not requested. Group feedback was offered to the participants on completion of the research and contact details of trauma counsellors were provided.

\section{Data analysis}

The data were analysed according to descriptive statistics to calculate means, frequencies and standard deviations for the ProQOL - R-IV and the Silencing Response Scale. The alpha co-efficients of the standardised measures were calculated. To investigate the relationship between compassion satisfaction, compassion fatigue, burnout and the silencing response, correlation co-efficients were generated Correlation is defined as the degree of relationship between two variables (Rosenthal \& Rosnow, 1991:61-70) The Pearson product-moment correlation co-efficient, or Pearson $r$, was used, which ranges from -1.00 (a perfect negative relationship) to 1.00 (a perfect positive relationship). The statistical significance was calculated at the 0.05 level to accommodate the relatively small sample size.

\section{Results and discussion Biographical description}

Frequencies and percentages were calculated to describe the sample. As the small sample size does not allow for investigation of possible relationships between biographical variables and the results obtained from the measures, these findings are confined to a description of the sample and serve to create a context for the findings.

\section{Age}

The final sample $(n=30)$ consisted of registered nurses ranging in age from 26 years to 57 years, with an average age of 38.70 years. The majority of the participants
(53.34\%, $n=16$ ) were in young adulthood (i.e. aged between 20 years and 40 years), whilst $46.67 \%(n=14)$ were in middle adulthood (i.e. aged between 41years and 65 years). Age is inversely correlated with both compassion fatigue and burnout, with younger trauma workers being more susceptible to these emotions (Caldas de Costa 2001; Figley 1995:1-21). The sample was almost equally distributed with regard to age, with $53.34 \%$ being between 20 years and 40 years old and $46.67 \%$ being over the age of 40 years, so it was expected that they would be less prone to compassion fatigue and burnout.

\section{Gender}

Two $(6.67 \%)$ participants were male and $93.33 \%(n=28)$ were female. Although statistics regarding gender distribution of males and females in the nursing profession are not available in South Africa, the figures reflect the situation in the USA, where $5.9 \%$ of nurses are male (Hilton 2000). Females may experience more severe symptoms of intense secondary traumatic stress symptoms than males (Brown, Fielding \& Grover 1999:312-325); however, this may be a reflection of job strain since women often carry dual home and work responsibilities (Burke 1996) or are more likely to disclose their emotions (Meyers \& Cornille 2002:39-57) This does not imply that men do not also experience secondary traumatic stress (Ursano et al. 1999:353-359; Van Minnen \& Keisjers 2000:189-200).

\section{Language}

English was the first language of $70.00 \%(n=21)$ of the participants, Afrikaans the first language of $10.00 \%(n=3)$ and Xhosa the first language of $20.00 \%(n=6)$. Language is not considered to be a significant variable per se since most training for intensive care nursing is undertaken in English.

\section{Nursing qualifications}

Of the 30 participants, $86 \%(n=26)$ had a basic diploma in nursing and $13.33 \%(n=4)$ were general nurses with an undergraduate (four-year) nursing degree. Half of the participants $(n=15)$ had an additional intensive care qualification. As previously indicated, intensive care nursing is stressful and findings on the level of qualification indicate that nurses with post-qualification training experience higher levels of stress (Tyler \& Ellison 1994:469-476; Rothmann, Rothmann \& Van der Colff 2006:22-33). There is a significant shortage of intensive care nurses in South Africa, which has led to an increasing reliance on registered comprehensive (general) nurses and newly qualified nurses to maintain service delivery (Schmollgruber 2007:247-248). This is confirmed by Scribante, Schmollgruber and Nel (2004:111-115), who reported that 53\% of all nurses working in South African ICUs are registered general nurses with a four-year degree. This implies that the focus of the training of the majority of this sample is on primary care and these nurses may lack an orientation towards intensive care nursing or nursing of critically ill patients. A lack of appropriate nursing skills is associated with an increased risk to patients (Ball 
\& McElligott 2003:226-238, Dang, Johantgen \& Pronovost 2002:219-222). The explosion of medical technology has also placed significant stress on intensive care nurses as the frequent blurring of the roles of nurses and doctors has led to an expansion in nurses' skills and activities and increased responsibility (Chaboyer, Dunn \& Najman 2001:153-161).

\section{Years of nursing experience}

The years of nursing experience ranged from 6 years to 30 years, with a mean of 18.16 years. The majority $(40.00 \%$, $n=12$ ) had more than 20 years' experience, $36.67 \%$ $(n=11)$ had between 10 years and 20 years' experience and $23.33 \%(n=7)$ had less than 10 years' experience. In a study of palliative care professionals, including nurses, Farber (2003:19-31) found that less experienced clinicians focused on the technical aspects of care, whilst those with more than 10 years' experience focused on their commitment to patients and their families, and developing trusting and open relationships. Experienced clinicians recognised the stressful nature of end-of-life care and were able to understand the experience from the perspective of the patient and family, as well as the meaning of the experience to themselves, both personally and professionally.

\section{Years of intensive care nursing experience}

The years of intensive care nursing experience ranged from 6 months to 20 years with a mean of 8.28 years. Sixty-three per cent $(n=19)$ had between 1year and 10 years' experience, $23.33 \%(n=7)$ had between 11year and 20 years' experience and $6.66 \%(n=2)$ had either less than 1 year's or more than 20 years' intensive care nursing experience. The longer nurses work in a stressful environment, the more likely they are to suffer burnout and consequently disengage from their patients (Adomat \& Killingworth 1994:912-922). Nurses who work in ICUs are exposed to the highest emotional risk, where stressors specific to intensive care nursing include high mortality and the nature of death in ICUs (Lally \& Pearce 1996:17-25).

The ProQOL - R-IV and Silencing Response Scales: The ProQOL - R-IV and the Silencing Response Scale were used to assess the potential or risk associated with (1) compassion satisfaction, (2) compassion fatigue and (3) burnout of intensive care nurses, and the activation of the silencing response respectively. Table 1 shows the means, standard deviations, minimum and maximum scores and the ranges obtained.

TABLE 1: Descriptive statistics and Chronbach alpha co-efficients of the subscales of the ProQOL - R-IV and the Silencing Response.

\begin{tabular}{|c|c|c|c|c|c|c|}
\hline Subscales & Mean & $\begin{array}{l}\text { Standard } \\
\text { deviation }\end{array}$ & Minimum & Maximum & Range & $\begin{array}{l}\text { Cronbach } \\
\text { alpha }\end{array}$ \\
\hline $\begin{array}{l}\text { Compassion } \\
\text { satisfaction }\end{array}$ & 36.67 & 8.14 & 14 & 48 & 34 & 0.89 \\
\hline $\begin{array}{l}\text { Compassion } \\
\text { fatigue }\end{array}$ & 18.10 & 7.44 & 6 & 33 & 27 & 0.80 \\
\hline Burnout & 24.80 & 6.38 & 13 & 39 & 26 & 0.69 \\
\hline $\begin{array}{l}\text { Silencing } \\
\text { response }\end{array}$ & 46.80 & 20.77 & 15 & 86 & 71 & 0.91 \\
\hline
\end{tabular}

The group mean compassion satisfaction score of 36.7 indicates moderate potential for compassion satisfaction, whilst the group mean compassion fatigue score of 18.1 indicates a high risk for compassion fatigue. The group mean burnout score was 24.8 , indicating a moderate risk for burnout. The group mean silencing response score of 46.8 indicates a moderate risk for activation of this response. The Cronbach alpha co-efficients for the compassion satisfaction (0.98), compassion fatigue (0.80) and burnout (0.69) subscales, as indicated on the table, confirm the reliability of the results. The Cronbach alpha co-efficient of the Silencing Response Scale (0.91) appears to indicate that the findings are reliable. Cronbach alpha co-efficients greater than 0.70 , the recommended minimum value for reliability (Nunally 1978:226), were observed for most indices, with the exception of the burnout score. Nunally (1978:226) argues that in the early stages of basic research, co-efficients between 0.50 and 0.69 are sufficient evidence of reliability. For the purpose of this basic exploratory study, a cut-off value of 0.60 was as used to indicate adequate reliability. The observed Cronbach alpha co-efficients for the indices all exceeded this cut-off point, thus confirming the reliability of the summated scores derived from the individual measuring instruments. Table 2 contains findings specific to the individual subscales.

\section{Compassion satisfaction subscale}

The majority of the participants $(73.34 \%, n=22)$ reported a moderate to high potential for experiencing compassion satisfaction. This reflects literature where personal growth, spiritual connection, hope and respect for human resiliency are positive consequences associated with caring for traumatised persons (Friedman \& Ortlepp 2002:213-222).

\section{Compassion fatigue subscale}

Results from the compassion fatigue subscale indicated that nearly all the participants were at an average to high risk of experiencing compassion fatigue. Research indicates that these results can be attributed to the nature of intensive care nursing (Lally \& Pearce 1996:17-25), where nurses have longer and more intimate contact with patients suffering from life-threatening conditions than other emergency workers such as paramedics and trauma nurses, whose contact with patients is usually raw but brief. Nkosi (2002) investigated the relationship between compassion fatigue and coping styles in nurses working in a hospital trauma unit and concluded that respondents' extremely high-risk position for developing compassion fatigue could also be attributed to working in the South African context of ongoing violence and frequent vehicle accidents. Caregivers may share, to varying degrees, the plight of those with whom they work. The 'shared fate' phenomenon may compound the threat of compassion fatigue (White 2001:1251-1254).

\section{Burnout subscale}

As indicated in Table 2, 89.90\% of respondents indicated a moderate to high risk of burnout. Health care professionals may suffer burnout as a result of interactions with their 
TABLE 2: Frequencies and percentages of the subscale scores and silencing response.

\begin{tabular}{|c|c|c|c|c|c|c|c|c|c|c|c|}
\hline Compassion satisfaction & $f$ & $\%$ & Compassion fatigue & $f$ & $\%$ & Burnout & $f$ & $\%$ & Silencing response & $f$ & $\%$ \\
\hline High potential (> 41) & 8 & 27.0 & High risk (> 17) & 12 & 40.0 & High risk (> 28) & 7 & 23.0 & High risk (95-150) & 0 & 0.0 \\
\hline Moderate potential (32-41) & 14 & 46.5 & Average risk (17-18) & 17 & 57.0 & Moderate risk (19-28) & 20 & 76.0 & Moderate risk (41-94) & 15 & 50.0 \\
\hline \multirow[t]{2}{*}{ Low potential $(<32)$} & 32 & 26.5 & Low risk $(<8)$ & 1 & 3.0 & Low risk (<19) & 3 & 10.0 & Some risk (21-40) & 13 & 43.0 \\
\hline & & & & & & & & & Minimal risk $(<21)$ & 1 & 7.0 \\
\hline Total & 30 & 100 & & 30 & 100 & & 30 & 100 & & 30 & 100 \\
\hline
\end{tabular}

$f$, frequency.

TABLE 3: Pearson product-moment correlation co-efficients for the ProQOL - R-IV subscales and the Silencing Response Scale.

\begin{tabular}{|c|c|c|c|c|c|c|c|c|}
\hline Subscale & $\begin{array}{l}\text { Comp. } \\
\text { satisfaction }\end{array}$ & $\begin{array}{l}\text { Practical } \\
\text { significance }\end{array}$ & $\begin{array}{l}\text { Comp. } \\
\text { Fatigue }\end{array}$ & $\begin{array}{l}\text { Practical } \\
\text { significance }\end{array}$ & Burn-out & $\begin{array}{l}\text { Practical } \\
\text { significance }\end{array}$ & $\begin{array}{l}\text { Silencing } \\
\text { response }\end{array}$ & $\begin{array}{l}\text { Practical } \\
\text { significance }\end{array}$ \\
\hline Comp.satisfaction & - & - & -0.19 & $\mathrm{~N} / \mathrm{A}$ & $-0.83^{*}$ & large & -0.22 & N/A \\
\hline Comp.fatigue & -0.19 & N/A & - & - & 0.4 & moderate & $0.67^{*}$ & large \\
\hline Burnout & $0.83 *$ & large & $0.40 *$ & moderate & - & - & 0.27 & N/A \\
\hline Silencing response & -0.22 & N/A & $0.67^{*}$ & large & 0.27 & N/A & - & - \\
\hline
\end{tabular}

Comp, compassion; N/A, not applicable.

${ }^{*} p<0.05$.

patients and / or the demands of their workplace. In the absence of exposure to traumatic material, emotional exhaustion experienced by a health care professional may be attributed to burnout related to working with difficult populations or other workplace demands, such as excessive workloads and role uncertainty. Scribante and Bhagwanjee (2007:1315-1318) go so far as to say that the acute shortage of intensive care nurses in South Africa leaves these nurses tired, unwell, and suffering from discontent and low morale. Nurses work under conditions of continuous emotional, cognitive and physical demands and the incidence of burnout is particularly high. The high risk for burnout in this sample, coupled with the high risk for compassion fatigue indicated earlier, are indicative of the risks facing the nurses who participated in this study.

\section{The silencing subscale}

With regard to the frequencies of responses to the Silencing Response scale, $93.33 \%$ indicated some to moderate risk of activation of this response. Compassion-fatigued caregivers use the silencing response as a means of ending their own discomfort or pain, protecting themselves from judgement, reprisal or ridicule and may result in distrust of colleagues (Gentry, Baranowsky \& Dunning 2002:123-137). TheSilencing Response subscale is known to correlate positively with the Compassion Fatigue subscale (Baranowsky 2002:155-171). Results from this sample confirmed this notion, indicating a distinct possibility for the activation of the silencing response together with the previously noted negative implications for nursing care.

\section{The relationships between the subscales}

Pearson product-moment correlation co-efficient, or Pearson's $r$, was used to determine the relationships between the subscales of the ProQOL - R-IV and the Silencing Response Scale. Scores above 0.361 were considered significant at a significance level of $p<0.05$. For practical significance, the following threshold values were used: $0.1<r<0.3$ for weak correlation, $0.3<r<0.5$ for moderate correlation and $r>0.5$ for strong correlation.

A slight negative correlation $(r=-0.19)$ was found between compassion satisfaction and compassion fatigue, which, according to Gravetter \& Wallnan (2004) can be regarded as an almost negligible relationship. These results are consistent with findings by Kraus (2005:81-83), who also found a weak negative correlation $(r=-0.20)$ between compassion satisfaction and compassion fatigue, suggesting that compassion satisfaction might be an important mediator for reducing burnout, but may co-exist with compassion fatigue (Folkman \& Moskowitz 2000:647-654). High levels of compassion fatigue may coexist with high levels of satisfaction in caregivers, when caregivers' professional activities carry significant and positive meanings for them. The stresses of caring for the critically ill may be counterbalanced by the associated benefits, for example, the satisfaction of controlling pain. Similarly, helplessness related to an inability to relieve suffering could be counteracted by a belief in possessing expertise with regard to keeping patients alive, as critically ill patients tend to be unstable and their progress uncertain. Moreover, compassion satisfaction is regarded as a moderator for compassion fatigue (Stamm 2005) and a protective factor against the negative consequences of exposure to traumatic events (Collins \& Long 2003:417-424).

A strong negative correlation or marked negative relationship $(r=-0.83)$ was found between compassion satisfaction and burnout in this sample, indicating that these two emotions do not easily co-exist. This is a statistically significant relationship. Kraus (2005:81-83), in a sample of mental health professionals, detected a moderate negative correlation $(r=-0.43)$ between compassion satisfaction and burnout. The co-occurrence of compassion satisfaction and burnout is unlikely. High compassion satisfaction and an altruistic desire to help even while working in distressing situations are not unusual, but place the individual at high risk for compassion fatigue and subsequent burnout.

A moderate but statistically significant positive correlation $(r=0.40)$ was found between compassion fatigue and burnout. These findings are consistent with research by Caldas da Costa (2001) and Kraus (2005:81-83) that indicated that the more compassion fatigue experienced, the higher the susceptibility to burnout, and vice versa. Burnout illustrates the end result of stress in the professional life of a caregiver. 
Burnout has a gradual onset and progresses in intensity over time, whereas compassion fatigue has a sudden onset and tends to be responsive to treatment and rapid amelioration. Burnout is equated to an extreme form of the exhaustive component of compassion fatigue and is frequently present in extreme cases of compassion fatigue (Caldas da Costa 2001). The distinction between the component of exhaustion in compassion fatigue and burnout is, therefore, a matter of degree.

The silencing response is activated by compassion-fatigued caregivers in order to end their own pain (Gentry, Baranowsky \& Dunning 2002:123-137). A weak negative correlation $(r=-0.22)$ was detected between compassion satisfaction and the silencing response. Given that compassion satisfaction is a direct result of positive engagement with the patient and an emotionally rewarding interaction, it stands to reason that the silencing response would not be activated.

For this sample a strong and statistically significant positive correlation $(r=0.67)$ was detected between compassion fatigue and the silencing response. This is a statistically significant finding. This was expected, considering established literature. Similarly, a weak positive correlation $(r=0.37)$ was detected between burnout and the silencing response. As discussed earlier, literature indicates that compassion fatigue may be an umbrella under which the silencing response rests. The silencing response could be either an indication of compassion fatigue or an attempt to avoid it on the caregiver's part.

\section{Limitations of the study}

The results of this study are in line with earlier research regarding intensive care nurses' negative experience of stress and burnout. Despite the limitations of the study (discussed below), the sample does appear to represent an important aspect of intensive care and indicates that the negative experiences of intensive care nurses appear inherent to the profession.

The approach was, however, limited in some aspects. The relatively small sample size and lack of random sampling imply that results cannot be generalised to all intensive care nurses and may not have represented the demographic composition of intensive care nurses in South Africa. Culture, or race, was not explored as a variable. Also, by selecting a sample from private intensive care facilities, the study did not take into account inherent stressors in under-resourced government institutions. The use of quantitative self-report scales may further have been affected by difficulties related to accuracy of reporting and self-disclosure. Finally, the nature of trauma encountered by intensive care nurses in private and public hospitals, as well as rural and urban settings may differ in frequency and intensity and this should be explored in future research.

\section{Recommendations}

The shortage of nurses, both nationally and internationally, necessitates researchers and clinical managers to continually seek a better understanding of the components of care that influence nurses, whether positively or negatively. Knowledge and education with regard to the negative effects of secondary trauma may facilitate prevention and early recognition of the risk for compassion fatigue and burnout and allow early interventions and necessary treatment to be instituted.

To manage the possible negative effects on the nursing staff and the potential impact on patient care, management should create an organisational culture that acknowledges and normalises secondary trauma reactions, and offer practical support to their staff. Peer supervision, supportive professional relationships and opportunities for caregivers to process the impact of their patients' traumatic material should be available, so that caregivers can take time to reflect on their experiences and develop self-awareness of their reactions to their work.

\section{Conclusions}

The stress experienced by intensive care nurses is related, in part, to environment, safety, resources and patient load. It may be presumed that nurses working in private care facilities would be more protected from these stresses than those in under-resourced hospitals as predominantly found in impoverished environments where these stressors are inherent. The sample for this study comprised intensive care nurses in two private, well-resourced and well-staffed hospitals. The setting, by implication, means that the stress of overwork and poor management, which is a feature in state hospitals in South Africa, should have less impact on the negative emotions associated with intensive nursing. Yet despite this, the mean scale scores suggest that the risk for compassion fatigue, burnout and activation of the silencing response was high to moderate in this sample. Results indicated only a moderate potential for compassion satisfaction for this sample.

\section{References}

Adomat, R. \& Killingworth, A., 1994, 'Care of the critically ill patient: The impact of stress on touch in intensive therapy units', Journal of Advanced Nursing 19, 912-922. doi:10.1111/j.1365-2648.1994.tb01169.x, PMid:8056920

Aronson, E., Kafrey, D. \& Pines, A.M., 1981, Burnout: From tedium to personal growth, The Free Press, New York.

Bailey, J.T., Steffen, SM., \& Grout, JW., 1980, 'The stress audit: Identifying the stressors of ICU nursing', Journal of Nursing Education 19, 15-25. doi:10.1016/ S0964-3397(03)00054-5

Ball, C. \& McElligott, M., 2003, 'Realising the potential of critical care nurses: an exploratory study of the factors that affect and compromise the nursing contribution to the recovery of critically ill patients', Intensive and Critical Care contribution to the recovery of critically ill patients', Inten
Nursing 19, 226-238. doi:10.1080/02678379950019770

Baranowsky, A.B., 2002, 'The silencing response in clinical practice: On the road to dialogue', in C.R. Figley (ed.), Treating compassion fatigue, pp. 155-170, Brunner-Routledge, New York.

Brown, J., Fielding, J. \& Grover, J., 1999, 'Distinguishing traumatic, vicarious and routine operational stressor exposure and attendant adverse consequences in a sample of police officers', Stress and Work 13(4), 312-325. doi:10.1054/ iccn.2001.1599, PMid:11853011

Burke, R.J., 1996, 'Work experiences, stress and health among managerial and professional women', in M.J. Schabracq, J.A.M. Winnubst \& C.L. Cooper (eds.), Handbook of Work and Health Psychology, pp.232-279, John Wiley, Chichester.

Caldas da Costa, P., 2001, 'An exploratory study of individual factors that predict susceptibility to compassion fatigue, burnout and intention to leave in South African trauma counsellors', Masters dissertation, Faculty of Humanities, University of the Witwatersrand. 
Cartledge, S., 2001 'Factors influencing the turnover of intensive care nurses', Intensive Care and Critical Care Nursing 17, 348-355. doi:10.1016/S0020-7489(00)00052-3

Chaboyer, W., Dunn, S. \& Najman, J., 2001, 'Factors influencing job valuation: a comparative study of critical care and non-critical care nurses', Internationa Journal of Nursing Studies 38, 153-161. doi:10.1046/j.1365-2850.2003.00620. PMid:12887633, doi:10.1046/j.1365-2850.2003.00526.x, PMid:12558918

Collins, S. \& Long, A., 2003, 'Too tired to care? The psychological effects of working with trauma', Journal of Psychiatric and Mental Health Nursing 10, 417-424. doi:10.1067/mhl.2002.122838

Dang, D., Johantgen, M. \& Pronovost, P., 2002, 'Postoperative complications: does intensive care unit staff nursing make a difference?', Heart Lung 31(3), 219-222. doi:10.1037/0736-9735.1.1.23

Danielli, Y., 1984, 'Psychotherapists' participation in the conspiracy of silence about the Holocaust', Psychoanalytic Psychology 1, 23-42. doi:10.1037//0736-9735.1.1.23

De Vos, A.S., Strydom, H., Fouche, C.B. \& Delport, C.S.L., 2005, Research at grass roots, Van Schaik, Pretoria.

Duquette, A., Kerouac, S., Sandhu, B.K. \& Beaudet, L., 1994, 'Factors related to nursing burnout: A review of empirical knowledge', Issues in Mental Health Nursing 15(4), 337-358. doi:10.3109/01612849409006913, PMid:8056566

Edwards, D., Burnard, P., Coyle, D., Fothergill, A. \& Hannigan, B., 2000, 'Stress and burnout in community mental health nursing: A review of the literature', Journal of Psychiatric and Mental Health Nursing 7, 7-14. doi:10.1046/j.13652850.2000.00258.x, PMid:11022506

Farber, S.J., 2003, 'Issues in end-of-life care: patient, caregiver, and clinician perceptions', Journal of Palliative Medicine 6(1), 19-31. doi:10.1089/10966210360510082, PMid:12710572

Figley, C.R., 1995, Compassion fatigue: Coping with secondary traumatic stress disorder in those who treat the traumatized, Bruner/Mazel, New York.

Folkman, S. \& Moskowitz, J.T., 2000, 'Positive affect and the other side of coping', American Psychologist 55, 647-654. doi:10.1037/0003-066X.55.6.647, PMid:10892207

Friedman, M. \& Ortlepp, P.K., 2002, 'Prevalence and correlates of secondary traumatic stress in workplace lay trauma counsellors', Journal of Traumatic Stress 15(3) 213-222. doi:10.1023/A:1015203327767, PMid:12092913

Garrett, D.K. \& McDaniel, A.M., 2001, 'A new look at nurse burnout: The effects of environmental uncertainty and social climate', Journal of Nursing Administration 31, 91-96. doi:10.1097/00005110-200102000-00009

Gentry, J.E., 2002, 'Compassion fatigue: A crucible of transformation', Journal of Trauma Practice 1(4), 37-61. doi:10.1300/J189v01n03_03

Gentry, J.E., Baranowsky, A.B. \& Dunning, K., 2002, ‘ARP: The accelerated recovery program for compassion fatigue', in C.R. Figley (ed.) Treating Compassion Fatigue, pp.123-137, Brunner-Routledge, New York.

Govender, G.S., 2007, 'Nursing Crisis', Carte Blanche, viewed 29 November 2010, from beta.mnet.co.za/carteblanche/article. aspx?id=3240

Gravetter, F.J. \& Wallnan, L.B., 2004, Statistics for the behavioural sciences, 6th edn. Thompson Wadsworth, Belmont, CA.

Hem, M.H. \& Heggen, K., 2004, 'Is compassion essential to nursing practice?', Contemporary Nurse 17, 19-31. PMid:17929733

Hilton, L., 2000, 'A few good men: Male nurses defy stereotypes and discrimination to find satisfaction in a female dominated profession', in Nurseweek, viewed 29 November 2010, from www.nurseweek.com/news/features/01-05/men.html

Jisika, C., 1995, 'Stress in nursing home staff. A review and a theoretical model', Journal of Applied Gerentology 14(4), 444-466. doi:10.1177/073346489501400406

Joinson, C., 1992, 'Coping with compassion fatigue', Nursing 22, 116-122. PMid:1570090

Killfedder, C, J, Power, K. G. \& Wells, T. 2001, 'Burnout in psychiatric nursing', Journa of Advanced Nursing 34, 383-396. doi:10.1046/j.1365-2648.2001.01769.x PMid:11328444

Kraus, V.I., 2005, 'Relationship between self-care and compassion satisfaction, compassion fatigue, and burnout among mental health professionals working with adolescent sex offenders', Counselling and Clinical Psychology Journal 2(1), 81-3.

Lally, I. \& Pearce, J., 1996, 'Intensive care nurses' perception of stress', Nursing in Critical Care 1, 17-25. PMid:9873336

Mathiva, L.R., 2002, 'ICUs worldwide: An overview of critical care medicine in South Africa', Critical Care 6, 22-23. doi:10.1186/cc1449, PMid:11940262, PMCid:137393, doi:10.1186/cc1685
McCann, L. \& Pearlman, L.A., 1990, 'Vicarious traumatization: A framework for understanding the psychological effects of working with victims', Journal of Traumatic Stress 3(1), 131-149. doi:10.1002/jts.2490030110, doi:10.1007/ BF00975140

McCloed, T., 1997, 'Work stress among community psychiatric nurses', British Journal of Nursing 6(10), 569-574.

Meyers, T.W. \& Cornille, T.A., 2002, The trauma of working with traumatized children in C.R. Figley (ed.) Treating Compassion Fatigue, Pp. 39-57, Brunner/Mazel, New York.

Nkosi, S.N., 2002, 'The relationship between compassion fatigue and coping styles in nurses working in a hospital trauma unit' MA dissertation, Faculty of Humanities, nurses working in a hospital trauma
University of the Witwatersrand.

Nolan, P., Cushway, D. \& Tyler, P., 1995, 'A measurement tool for assessing stress among mental health nurses', Nursing Standard 9(46), 36-39. PMid:7646978

Nunally, J., 1978, Psychometric theory, 2nd edn, McGraw-Hill, New York.

Park, C.L., Cohen, L.H. \& Murch, R.L., 1996, 'Assessment and prediction of stressrelated growth', Journal of Personality 64, 71-105. doi:10.1111/j.1467-6494.1996. related growth', Journal of
tb00815.x, PMid:8656319

Pearlman, L.A. \& Saakvitne, K.W., 1995, Trauma and the therapist: Countertransference and vicarious traumatization in psychotherapy with incest survivors, W.W. Norton, New York.

Prosser, D., Dohnson, S., Kuipers, E., Szmukler, G., Bebbington, P. \& Thornicroft, G. 1997, 'Perceived sources of work stress and satisfaction among hospital and community mental health staff, and their relation to mental health, burnout and job satisfaction', Journal of Psychosomatic Research 43(1), 51-59. doi:10.1016/ S0022-3999(97)00086-X

Romano, J.L., 1992, 'Psychoeducational interventions for stress management and well-being', Journal of Counselling and Development 71, 190-202.

Romey, W.D., 2005, Loyalty: A key concept to understand therapists' symptoms of compassion fatigue and vicarious trauma, Simon Fraser University, British Columbia.

Rosenthal R. \& Rosnow, R., 1991, Essentials of Behavioural Research Methods and Data Analysis, 2nd edn., McGraw-Hill, New York.

Rothmann, J.C., Rothmann, S. \& Van der Colff, J.J., 2006, 'Occupational stress of nurses in South Africa', Curationis 29(2), 22-33. PMid:16910131

Schmollgruber, S., 2007, 'Organization, strengths and difficulties of South African intensive care nurses', Intensive \& Critical Care Nursing 23(5), 247-248. doi:10.1016/j.iccn.2007.07.001, PMid:17720503

Scribante, J. \& Bhagwanjee, S., 2007, 'National audit of critical care resources in South Africa: Nursing profile', South African Medical Journal 97(3), 1315-1318. PMid:18265912

Scribante, J., Schmollgruber, S. \& Nel, E., 2004, 'Perspectives on critical care nursing: South Africa', World Critical Care Nursing 3(4), 111-115.

Sheldon, T., 2000, 'The day the world blew up', Nursing Times 96, 12. PMid:11962781

Sherman, D.W., 2004, 'Nurses' stress and burnout: How to care for yourself when caring for patients and their families experiencing life-threatening illness', American Journal of Nursing 104(5), 48-56. PMid:15166716

Stamm, B.H., 1997, Work-related secondary traumatic stress. PTSD Research Quarterly $8(2), 1-8$.

Stamm, B.H., 2005, ProQOL Manual, Sidran Press, Lutherville.

Thornton, P.I., 1992, 'The relation of coping, appraisal, and burnout in mental health workers', Journal of Psychology 126(3), 261-271. PMid:1527773

Tyler, P. \& Ellison, R., 1994, 'Sources of stress and psychological well-being in high dependency nursing', Journal of Advanced Nursing 19, 469-476. doi:10.1111/j.1365-2648.1994.tb01109.x, PMid:8014307

Ursano, R., Fullerton, C., Vance, K. \& Kao, T., 1999 'Post-traumatic stress disorder and identification in disaster workers', American Journal of Psychiatry 156(3), 353359. PMid:10080548

Van Minnen, A. \& Keisjers, G., 2000, 'A controlled study into the cognitive effects of exposure treatment on trauma therapists', Journal of Behaviour Therapy and Experimental Psychiatry 31(3/4), 189-200. doi:10.1016/S0005-7916(01)00005-2

Vettor, S.M., Kosinski, J.R. \& Frederick, A., 2000, 'Work stress burnout in emergency medical technicians and the use of early recollections', Journal of Employment Counselling 37(4), 216-229.

White, G.D., 2001, 'Near Ground Zero: Compassion fatigue in the aftermath of September 11', Traumatology 74, 1251-1254.

Zimering, R., Munroe, J. \& Gulliver, S.B., 2003, Secondary traumatization in mental health care providers, viewed February 2007, from www.psychiatrictimes.com/ ptsd/context/article/10168/47641 